\title{
Comparative study of the dental substrate used in shear bond strength tests
}

\section{Estudo comparativo do tipo de substrato dental utilizado em testes de resistência de união ao cisalhamento}

\author{
Murilo Baena Lopes* \\ Mário Alexandre Coelho Sinhoreti** \\ Lourenço Correr Sobrinho** \\ Simonides Consani**
}

\begin{abstract}
The purpose of this study was to compare shear bond strength values obtained in human enamel and dentin with the values obtained in bovine teeth using two adhesive systems with different actions. Forty human tooth half-crowns and forty bovine tooth crowns were flattened to a minimum plain area of $5 \mathrm{~mm}$ in diameter. The samples were divided in four groups of 20 specimens each: 1) human enamel; 2) bovine enamel; 3) human dentin; 4) bovine dentin. The samples of each group were divided in 2 subgroups of 10 samples each, according to the adhesive system used: 1) Scotchbond Multi-Purpose (SBMP); and 2) Clearfil Liner Bond 2V (CLB2V) applied according to the manufacturer's recommendations. Afterwards, restorations of $Z 100$ composite with cylindrical shape $(4 \mathrm{~mm}$ diameter $\mathrm{x} 5 \mathrm{~mm}$ height) were made using a metallic mold to submit the samples to shear bond testing on an Instron universal testing machine, at a crosshead speed of $0.5 \mathrm{~mm} / \mathrm{min}$. The data were submitted to ANOVA and Tukey's test (5\%). In enamel, there was no statistical difference between bovine and human teeth for SBMP (7.36 MPa, human; 8.24 MPa, bovine), nor for CLB2V (10.01 MPa, human; 7.95, bovine). In dentin, SBMP showed a statistically lower mean on human dentin $(7.01 \mathrm{MPa})$ than on bovine dentin $(11.74 \mathrm{MPa})$. For CLB2V, there was no statistical difference between human (7.43 $\mathrm{MPa})$ and bovine $(9.27 \mathrm{MPa})$ substrates.
\end{abstract}

DESCRIPTORS: Dentin-bonding agents; Dentin; Dental enamel.

\begin{abstract}
RESUMO: O propósito deste estudo foi comparar os valores de resistência de união sobre esmalte e dentina humanos com os valores obtidos em dentes bovinos, utilizando dois sistemas de união com princípios de atuação distintos. Para isso, desgastaram-se 20 meias coroas dentais humanas e 40 coroas bovinas, até obter uma área plana de pelo menos $5 \mathrm{~mm}$ de diâmetro. As 80 amostras foram separadas em 4 grupos de 20 amostras cada, sendo: 1) dente humano em esmalte, 2) dente bovino em esmalte, 3) dente humano em dentina, 4) dente bovino em dentina. As amostras de cada grupo foram divididas em 2 subgrupos de 10 amostras cada, de acordo com o sistema de união utilizado: 1) Scotchbond Multi-Uso (SBMU); e 2) Clearfil Liner Bond 2V (CLB2V). Em seguida, confeccionou-se um cilindro do compósito Z100 (4 mm de diâmetro x $5 \mathrm{~mm}$ de altura) utilizando-se uma matriz bipartida, para submeter os corpos-de-prova ao ensaio de cisalhamento numa máquina de ensaio Instron com velocidade de $0,5 \mathrm{~mm} / \mathrm{min}$. Os dados foram submetidos à análise de variância e as médias, ao teste de Tukey (5\%). Em esmalte, não se verificou diferença estatística entre os dentes humanos e bovinos para os materiais SBMU (7,36 MPa, humano; e 8,24 MPa, bovino) e CLB2V (10,01 MPa, humano; e 7,95 MPa, bovino). Verificou-se que o SBMU apresentou média estatisticamente inferior em dentina humana (7,01 MPa), quando comparado à dentina bovina (11,74 MPa). Para o material CLB2V, não houve diferença estatística entre os substratos humano (7,43 $\mathrm{MPa})$ e bovino $(9,27 \mathrm{MPa})$.
\end{abstract}

DESCRITORES: Adesivos dentinários; Dentina; Esmalte dentário.

\section{INTRODUCTION}

Since the acid-etch technique was first introduced in dentistry by Buonocore ${ }^{2}$ (1955), phosphoric acid has been routinely used to roughen the enamel surface in order to create micromechanical retention with resin composites. The success obtained with enamel inspired its use on dentin sur- faces as well. However, with the use of early hydrophobic resins, acid treatment of dentin did not produce bond strengths similar to those obtained on enamel surfaces ${ }^{13}$.

After that, adhesive systems incorporating acid-etching and hydrophilic monomers have been developed. The enamel and dentin acid-etching could be done simultaneously ${ }^{8}$ and there was an

\footnotetext{
*Graduate Student, **Professor - Dental Materials Area, Department of Restorative Dentistry, School of Dentistry of Piracicaba, State University of Campinas.
} 
Lopes MB, Sinhoreti MAC, Correr Sobrinho L, Consani S. Comparative study of the dental substrate used in shear bond strength tests. Pesqui Odontol Bras 2003;17(2):171-5.

increase in the adhesive bond strength. With the new adhesive systems, a "primer" became necessary after the acid-etching and before the bonding agent. It increased the wettability of the dentin surface for the penetration of the adhesive agent.

Recently, "one-bottle" adhesive systems were introduced in dentistry. They combined the "primer" and the adhesive functions into a sole solution. These systems require at least two layers of the solution and a previous enamel and dentin acid-etching.

Nowadays, "self-etching" adhesive systems have currently combined the tooth surface etching and primer steps to treat enamel and dentin, which are demineralized allowing the adhesive to infiltrate. They have been developed by raising the concentration of the acid adhesive monomers from their original $5-6 \%$ concentration to $20 \%$ or more $^{11,16}$. By dissolving the acid monomers in 2-hydroxyethylmethacrylate (HEMA) and because of its low $\mathrm{pH}$, it resulted in a satisfactory conditioning system ${ }^{9,19}$.

To evaluate adhesive bond strength, plenty of in vitro research has been developed using extracted human teeth, which are, however, more and more difficult to obtain because of preventive dentistry advances. Therefore, it became necessary to look for an alternative substrate. As mammalian teeth are histologically and morphologically similar ${ }^{17}$, investigators have turned to teeth from bovine, ovine, equine, or swine to provide quantities of standardized material for their studies. Schilke et $a l .{ }^{14}$ (2000) verified that there were no statistically significant differences neither in the number of tubules per $\mathrm{mm}^{2}$ nor in their diameters in corresponding coronal dentine layers of human deciduous and permanent molars, and of bovine central incisor.

The size and availability make bovine incisors preferable for bond strength research ${ }^{4,12}$. However, there is some concern about whether data obtained from bovine teeth can be applied to human teeth and valid in a clinical situation ${ }^{10,12}$.

Hence, this study searched for more information about the alternative substrate for human teeth. Therefore, a comparison was made between human and bovine enamel and dentin as regards shear bond strength, using two different adhesive systems with different mechanisms of action.

\section{MATERIALS AND METHODS}

Forty freshly extracted, non carious human molars and eighty bovine incisors were obtained and stored in $0.9 \%$ sodium hypochlorite for a maximum of 90 days. The roots of the teeth were removed. Human crowns were sectioned in a bucco-lingual direction, amounting to forty half-crowns. The crowns were then embedded with the vestibule (bovine) or proximal (human) surface exposed in plastic tubes with self-cured acrylic resin. The samples were assigned to 4 groups: 1) human enamel, 2) bovine enamel, 3) human dentin, and 4) bovine dentin; with 20 specimens in each group. The vestibule or proximal surfaces were ground wet in a polishing machine (APL-4 Arotec, Cotia, Brazil) with 180 grit, followed by 400 and 600 grit silicon carbide paper to create a $5 \mathrm{~mm}$ diameter flat surface on enamel or dentin. To delimitate the testing area, a circular adhesive tape with a central orifice of $4 \mathrm{~mm}$ in diameter was applied.

The samples of each group were assigned to two subgroups of 10 specimens each, according to the adhesive system used: 1) Scotchbond Multi-Purpose (3M Dental Products Division, St. Paul, MN, USA), 2) Clearfil Liner Bond 2V (Kuraray Co. Ltd., Osaka, Japan).

After these superficial treatments, a stainless steel mould ( $4 \mathrm{~mm}$ in diameter and $5 \mathrm{~mm}$ in height) was placed against the specimen to receive the filling material (Z100, 3M Dental Products Division, St. Paul, MN, USA). The resin composite was inserted in three increments of equal height; each one of them was light-cured (XL-3000, 3M Dental Products Division, St. Paul, MN, USA) for $40 \mathrm{~s}$, with a light intensity of $530 \mathrm{~mW} / \mathrm{cm}^{2}$. After mould removal, the specimens were stored in distilled water at $37^{\circ} \mathrm{C}$ for 24 hours. After this period, the specimens were positioned in a universal testing machine (Instron, model 4411) to be submitted to a shear bond strength test, performed at a speed of $0.5 \mathrm{~mm} / \mathrm{min}$ until breakdown. A stainless steel strip involved the resin cylinder and was fixed in the inferior mordant. A metal jig, which involved the specimen, was fixed in the superior mordant. The obtained data $\left(\mathrm{kgf} / \mathrm{cm}^{2}\right)$ were transformed in $\mathrm{MPa}$ and analyzed with ANOVA and Tukey's test $(\mathrm{p}=0.05)$.

\section{RESULTS}

The shear bond strength results were submitted to ANOVA with factorial schema. The factors 
Lopes MB, Sinhoreti MAC, Correr Sobrinho L, Consani S. Comparative study of the dental substrate used in shear bond strength tests. Pesqui Odontol Bras 2003;17(2):171-5.

TABLE 1 - Mean of shear bond strength (MPa) for Clearfil Liner Bond 2V, on human and bovine enamel and dentin.

\begin{tabular}{l|c|c}
\hline \hline & Enamel (SD) & Dentin (SD) \\
\hline Human & $10.01 \mathrm{a}(3.22)$ & $7.43 \mathrm{a}(2.09)$ \\
\hline Bovine & $7.95 \mathrm{a}(1.98)$ & $9.27 \mathrm{a}(2.69)$ \\
\hline \hline
\end{tabular}

Means with same letters on column indicate no significant difference for Tukey's test (5\%). $\mathrm{SD}=$ standard deviations .

TABLE 2 - Mean of shear bond strength (MPa) for Scotchbond Multi-Purpose, on human and bovine enamel and dentin.

\begin{tabular}{l|c|c}
\hline \hline & Enamel (SD) & Dentin (SD) \\
\hline Human & $7.36 \mathrm{a}(1.58)$ & $7.01 \mathrm{a}(2.26)$ \\
\hline Bovine & $8.24 \mathrm{a}(2.47)$ & $11.74 \mathrm{~b}(3.78)$ \\
\hline \hline
\end{tabular}

Means with same letters on column indicate no significant difference for Tukey's test (5\%). $\mathrm{SD}=$ standard deviations.

are: the substrate, analyzed for its nature (enamel or dentin); the origin, analyzed for animal species (human or bovine). Two analyses were carried out: one for Clearfil Liner Bond $2 \mathrm{~V}$ and another for Scotchbond Multi-Purpose. This was done because the purpose of the study was not to evaluate the two adhesive systems themselves, but compare the adhesive systems with dissimilar mechanisms of action in different substrates. The means were submitted to Tukey's test with $5 \%$ of significance and they are presented on Tables 1 and 2 .

For Clearfil Liner Bond 2V, there was no significant statistical difference $(\mathrm{p}>0.05)$ between bovine and human teeth for both enamel and dentin, as can be seen on Table 1 .

For Scotchbond Multi-Purpose, there was no significant statistical difference $(p>0.05)$ between bovine and human teeth for enamel, as seen on Table 2. However, on dentin, the bovine tooth shear bond mean was higher than that of the human tooth, and there was some statistical difference $(\mathrm{p}<0.05)$

\section{DISCUSSION}

The search for an alternative substrate to human teeth for studies on bond strength and microleakage has increased, arousing the interest of some researchers.
The strength of the adhesive bonds between restorative materials and dentin is affected by the number of dentinal tubules per $\mathrm{mm}^{2}$ and by their diameter, as well as the relative amount of intratubular and intertubular dentin ${ }^{10}$. According to Nakamichi et al. ${ }^{10}$ (1983), a sufficient area of substrate could be obtained in different dentin depths of bovine incisors, but only the superficial layer could be considered a substitute to human dentin. The dentin in bovine incisors presents larger dentinal tubules and more porous on intertubular dentin than human molars ${ }^{12}$.

Bovine enamel is more porous than human enamel, so it presents a higher diffusion and rate of progress of artificial carious lesion ${ }^{5,6,7}$. Besides, it presents thinner crystallites than human enamel and it has a different structure between prisms ${ }^{18}$. Edmunds et al. ${ }^{5}$ (1988) using bacterial culture and acid gel studied artificial caries in bovine, equine, and ovine enamel. They verified that the lesions depths in these animal teeth were almost two times bigger than in the human teeth.

The enamel rich in carbonate was found to be particularly vulnerable to acid attack ${ }^{19}$. According to Sydney-Zax et al..$^{15}$ (1991), the carbonate concentration on bovine enamel was higher than in human enamel. It is probable that the same occurs with dentin.

This study found higher shear bond strengths for bovine substrate when SBMP was used. As bovine substrate presents lower mineral quantity and higher carbonate concentration, it is more susceptible to acid-etching; in other words, in the same period of time, the dissolution of enamel crystals, the opening of dentinal tubules and the demineralization of inter and intratubular dentin are more pronounced in bovine teeth than in human teeth. As to enamel, though the statistical analysis showed no difference between bovine $(8.24 \mathrm{MPa})$ and human $(7.36 \mathrm{MPa})$ substrates, higher values were observed for bovine enamel. There was some statistical difference regarding dentin, with higher values in bovine (11.74 MPa) than in human (7.01 MPa) dentin. Maybe these results were obtained because it is easier for the adhesive system to penetrate into the bovine demineralized dentin, because of the greater quantity of dentinal tubules as well as their greater diameter. Their longer and thicker tags may induce higher bond strength values on shear or traction tests.

With Clearfil Liner Bond 2V, there was no difference between human and bovine substrates, both 
Lopes MB, Sinhoreti MAC, Correr Sobrinho L, Consani S. Comparative study of the dental substrate used in shear bond strength tests. Pesqui Odontol Bras 2003;17(2):171-5.

in enamel and dentin. However, Nakamichi et al. ${ }^{10}$ (1983) observed a higher bond strength to human enamel than to bovine enamel. In this study, human enamel also presented a few higher values, but without statistical difference. Maybe these results were because self-etching systems do not require a previous acid-etching procedure with phosphoric acid. Hence, the acid monomers of these systems will act on the enamel surface, demineralizing and penetrating it. A close contact with the dental surface is, nevertheless, necessary. According to Yu, Chang ${ }^{20}$ (1966), bovine enamel presents lower superficial energy than human enamel. This could explain why Clearfil Liner Bond $2 \mathrm{~V}$ showed smaller results on bovine enamel.

As to Clearfil Liner Bond $2 \mathrm{~V}$ on dentin, there were a few high values for bovine teeth compared with human teeth, although with no statistical difference. The Scotchbond Multi-Purpose presented the same behavior, albeit with statistical difference. An explanation for these results would be that acid-etching before the application of the bonding agent could permit a higher resin penetration in dentinal tubules and in peri- and intratubular dentin. With the Clearfil Liner Bond $2 \mathrm{~V}$ system, the resin penetration would be less intense on both substrates. However, when analyzing bond strength values, they are similar to those

\section{REFERENCES}

1. Arends J, Jongebloed WL. Crystallites dimensions of enamel. J Biol Buccale 1978;6:161-71.

2. Buonocore MG. A simple method of increasing the adhesion of acrylic filling materials to enamel surfaces. J Dent Res 1955;34:849-53.

3. Buonocore MG, Matsui A, Gwinett AJ. Penetration of resin dental materials into enamel surfaces with reference to bonding. Arch Oral Biol 1968;13:61-70.

4. Burrow MF, Sano H, Nakajima M, Harada N, Tagami J. Bond strength to crown and root dentin. Am J Dent 1996;9:223-9.

5. Edmunds DH, Whittaker DK, Green RM. Suitability of human, bovine, equine, and ovine tooth enamel for studies of artificial bacterial carious lesions. Caries Res 1988; 22:327-36.

6. Featherstone JD, Mellberg JR. Relative rates of progress of artificial lesions in bovine, ovine and human enamel. Caries Res 1981;15:109-14.

7. Flim GJ, Arends J. Diffusion of ${ }^{45} \mathrm{Ca}$ in bovine enamel. (1977) apud Mellberg JR. J Dent Res 1992;71:913-9.

8. Fusayama T, Nakamura M, Kurosaki N, Iwaku M. Non-pressure adhesion of a new adhesive restorative resin. J Dent Res 1979;58:1364-70. of the Scotchbond Multi-Purpose system. Nevertheless, when a shear force is applied, a thicker hybrid layer with larger and longer resin tags, similar to those obtained with Scotchbond Multi-Purpose, may possibly make the difference between the substrates for one system and not for the other.

This study verified that when bovine teeth were used instead of human teeth in laboratory tests of bond strength, it is necessary to be careful because the results will not always be proportional between the two substrates.

\section{CONCLUSION}

1. When Clearfil Liner Bond 2V was used, the bovine and human dentin and enamel were equivalent as regards shear bond strength values.

2. The Scotchbond Multi-Purpose system presented no statistical differences on enamel, but on dentin the bovine substrate showed higher bond strength values than the human substrate.

3. The use of bovine teeth in place of human teeth in laboratory tests of shear bond strength seems to be partially valid because the obtained values were not always proportional to the two substrates; this depends on the adhesive system used.
9. Miyazaki M, Hirohata N, Takagaki K, Onose H, Moore BK. Influence of self-etching primer drying time on enamel bond strength of resin composites. J Dent 1999;27:203-7.

10. Nakamichi I, Iwaku M, Fusayama T. Bovine teeth as possible substitutes in the adhesion test. J Dent Res 1983;62:1076-81.

11. Pashley DH, Sano H, Yoshiyama M, Carvalho M. Dentin, a dynamic bonding substrate: the effects of dentin variables on resin adhesion. In: Shimono M, Maeda T, Suda H, Takahashi K. Dentin/pulp complex. Tokyo: Quintessence; 1996. p.11-21.

12. Reeves GW, Fitchie JG, Hembree JH Jr, Puckett AD. Microleakage of new dentin bonding systems using human and bovine teeth. Oper Dent 1995;20:230-5.

13. Rider M, Tanner AN, Kenny B. Investigation of adhesive properties of dental composite materials using an improved tensile test procedure and scanning electron microscopy. J Dent Res 1977;56:368-78.

14. Schilke R, Lisson JA, Bauss O, Geurtsen W. Comparison of the number and diameter of dentinal tubules in human and bovine dentine by scanning electron microscopic investigation. Arch Oral Biol 2000;45:355-61.

15. Sydney-Zax M, Mayer I, Deutsch D. Carbonate content in developing human and bovine enamel. J Dent Res 1991;70:913-6. 
Lopes MB, Sinhoreti MAC, Correr Sobrinho L, Consani S. Comparative study of the dental substrate used in shear bond strength tests. Pesqui Odontol Bras 2003;17(2):171-5.

16. Watanabe I, Nakabayashi N, Pashley DH. Bonding to ground dentin by a phenyl-P self-etching primer. J Dent Res 1994;73:1212-20.

17. Weichert CK, Presch W. Elements of chordate anatomy. $4^{\text {th }}$ ed. New York: McGraw-Hill Company; 1975.

18. Whittaker DK, Green RM, Edmunds DH. Structural characteristics of bovine enamel [abstract 208]. J Dent Res 1983;62:439.
19. Yoshiyama M, Matsuo T, Ebisu S, Pashley D. Regional bond strengths of self-etching/self-priming adhesive systems. J Dent 1998;26:609-16.

20. Yu KC, Chang R. Adhesive restorative dental materials II. Approaches to achieve adhesion. National Institute of Dental Research: U. S. Department of Health, Education and Welfare (1966) apud Nakamichi I, Iwaku M, Fusayama T. J Dent Res 1983;62:1076-81.

Recebido para publicação em 24/07/02 Enviado para reformulação em 19/03/03 Aceito para publicação em 16/04/03 